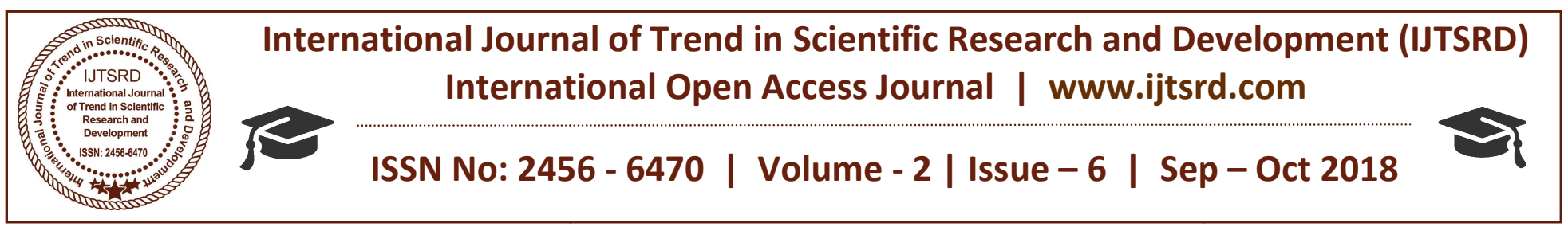

\title{
Coal Ash-Bentonite Mixture as Landfill Liner
}

\author{
Er Anu ${ }^{1}$, Javed Iqbal ${ }^{2}$ \\ ${ }^{1}$ Assistant Professor, ${ }^{2} \mathrm{M}$. Tech Student \\ Civil Engineering Department, Galaxy Global Group of Institutions, Haryana, India
}

\section{ABSTRACT}

Landfills are highly engineering containment systems, designed to minimize the impact of soiled waste on the environment and human health. In case of economically developing countries the design of a liner varies, that depends upon number of factors such as potential of the landfill polluting the land and water environments, the local hydrogeology and meteorology, and the availability of suitable materials and monetary resourced. Landfill is a land disposal site for waste and its Preparation, management and control must be of the highest standard to minimize the risks to human health and the environment. Well-constructed and maintained landfills are safer than open dumping sites. Landfill liners are exposed to various types of physical, chemical and biological processes which gets affected by leach ate produced from the decomposition of waste dumps. The aim is to avoid any hydraulic connection between the wastes and the surrounding environment, particularly groundwater. To ensure this, the important characteristics for compacted landfill liners are; selection of materials, hydraulic conductivity, strength, compressibility and contaminant retention capacity. Compacted clay liners are of low cost, large leach ate attenuation capacity and resistance to damage. Natural clay is often fractured and cracked and due to non-availability of suitable soil at a site, it is necessary to mix imported clay materials with industrial wastes to achieve a suitable material. Usually soil, which is rich in clay minerals is used for compacted liner materials. But instead of clay, mixture of expansive soil such as bentonite with fly ash can be used as compacted liner materials for their low hydraulic conductivity which is required to be less than $1.00 \times 10^{\wedge}-7 \mathrm{~cm} / \mathrm{sec}$. Bentonite was mixed with fly ash in $2,48,12,16$, and $20 \%$ by dry weight.
Keyword: Permeability, bentonite, fly ash, landfill liner, pond ash

\section{INTRODUCTION}

Landfill are highly Engineering constraint systems, made to reduce the impact of solid waste (refuse, trash, and garbage) on the environment and human health. today's landfills, the waste is accommodated by a direct system and the main purpose of these direct system is to detach the landfill material from the environment in order to protect the soil and ground water from pollution originating from the landfills. Leach ate may change from the contaminate soil and ground water, thus showing a thread to human and environmental health. usually soil rich in clay minerals are used as compacted liner materials for their low pneumatic conductivity which is required to be less than $1.00 \times 10-7 \mathrm{~cm} / \mathrm{s}$ (Daniel, 1987; 1990; Benson and Trast, 1995). In place of clay, mixture of swelling soil such as 'bentonite with fly ash and pond ash can is used as crushed obstacle (Brian et al. 2000). The present work focuses at finding a correct mixture of fly ash and bentonite as well as pond ash and bentonite that can be used as compacted clay liner.

\section{MATERIALS USED}

Fly ash

Fly ash is very small sized, glassy powder residue as a result of coal combustion in power plants. It is pozzolanic in nature and consist mainly of alumina, iron and silica, e materials are oven dried at $105^{\circ} \mathrm{C}$ $110^{\circ} \mathrm{C}$, prior to the tests. Fly ash used for the experimental purpose is brought from Chenab valley power project (CVPP Ltd) in Jammu and Kashmir. 
International Journal of Trend in Scientific Research and Development (IJTSRD) ISSN: 2456-6470

\begin{tabular}{|c|c|c|c|}
\hline Physical Parameter & Fly Ash & Pond Ash & Bentonite \\
\hline Color & Grey & Light grey & Cream \\
\hline Shape & Rounded/sub-rounded & Rounded/sub-rounded & Platy \\
\hline Uniformity coefficient & 5.71 & 8.15 & - \\
\hline Coefficient of curvature & 1.27 & 0.83 & - \\
\hline Specific gravity & 2.33 & 1.95 & 2.89 \\
\hline Plasticity Index (\%) & Non-plastic & Non-plastic & 236 \\
\hline
\end{tabular}

Table 1 Physical property of fly ash, pond ash and bentonite

Pond ash Pond ash is obtained from the wet disposal of fly ash along with bottom ash as slurry, in engineered structures called ash pond. It is a waste product from boilers and contains relatively coarser particles. The pond ash used for this work is collected from (CCPP Ltd) Jammu and Kashmir.

Bentonite The bentonite used for the project work is Sodium bentonite which is naturally occurring hydrated aluminum silicate clay. It is highly plastic soil and exhibits extremely high swelling and water absorbency properties. Grain size distributions of these materials are shown in Figure 1. Physical properties of these materials are shown in Table 1.

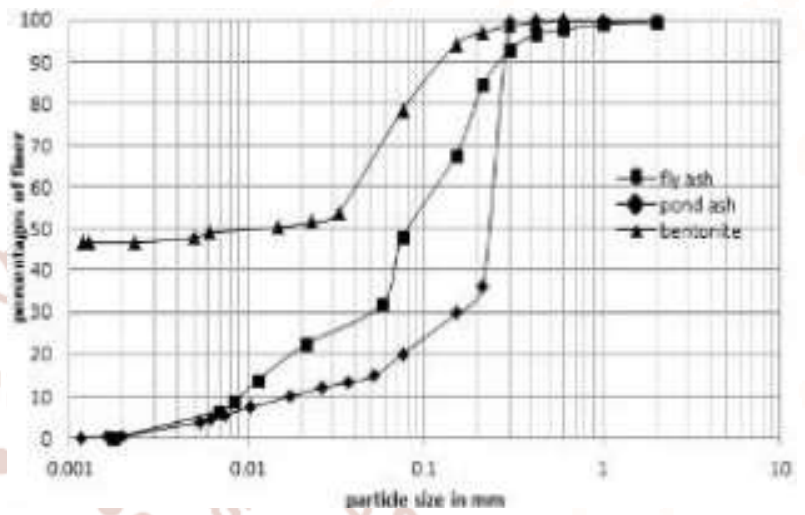

Fig. 1 Grain size distribution curve of fly ash, pond ash and bentonite

TEST RESULTS AND DISCUSSION

Determination of Atterberg Limits Liquid Limit (LL)

The Liquid limit of fly ash and pond ash are found to be $50.5 \%$ and $35 \%$ respectively which is very low compared to that of bentonite. Bentonite used for the project work has a liquid limit of $300 \%$.

\begin{tabular}{|c|c|c|c|c|c|c|c|c|}
\hline \multicolumn{3}{|c|}{ Bentonite } & \multicolumn{2}{c|}{ Bentonite-fly ash mixture } & \multicolumn{3}{c|}{ Bentonite-pond ash mixture } \\
\hline$(\%)$ & $\begin{array}{c}\text { Liquid } \\
\text { limit }\end{array}$ & $\begin{array}{c}\text { Plastic } \\
\text { limit }\end{array}$ & $\begin{array}{c}\text { Linear } \\
\text { shrinkage }\end{array}$ & Diff free swell & $\begin{array}{c}\text { Liquid } \\
\text { limit }\end{array}$ & $\begin{array}{c}\text { Plastic } \\
\text { limit }\end{array}$ & $\begin{array}{c}\text { Linear } \\
\text { shrinkage }\end{array}$ & Diff free swell \\
\hline 0 & 50.5 & NP & 41.5 & - & 35 & NP & 27 & - \\
\hline 2 & 51.5 & NP & 41 & - & 42 & NP & 26 & - \\
\hline 4 & 52 & NP & 40 & 32.5 & 45 & NP & 25 & 51 \\
\hline 8 & 54 & NP & 39 & 87 & 50 & NP & 24 & 120 \\
\hline 12 & 63 & 43 & 37 & 136 & 55 & 28.5 & 22.5 & 193 \\
\hline 20 & 71 & 44 & 35.5 & 177 & 62 & 32.5 & 20.5 & 250 \\
\hline
\end{tabular}

Table2. Geotechnical properties of bentonite-fly ash mixture and bentonite - pond ash mixture

Plastic limit The plastic limit of bentonite is found to be $65 \%$. When it is added to the non-plastic coal ash, the mixture shows plasticity after about $12 \%$ of bentonite content in it. The plastic limit of fly ash is seen to be about $43-44 \%$ with an increase in bentonite content of $12-20 \%$, where as in case of pond ash the increase in plastic limit is about $28-32.5 \%$.

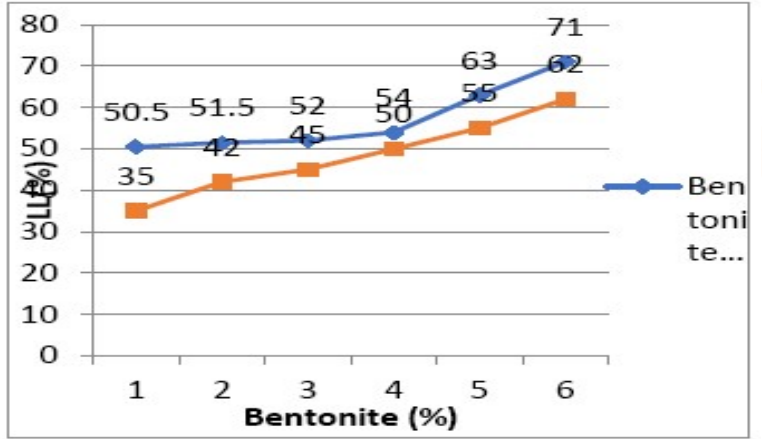

Fig.2 Variation of Liquid Limit with bentonite content 
Shrinkage limit The sample preparation involved taking about $30 \mathrm{~g}$ of dry sample passing through 425 microns IS sieve and thoroughly mixing with distilled water to form a paste, which was left standing for 24 hours. The consistency of the paste was workable enough to place it in the shrinkage dish without entrapping air bubbles. Since bentonite was being tested, the water added was about 6\%-10\% more than the liquid limit

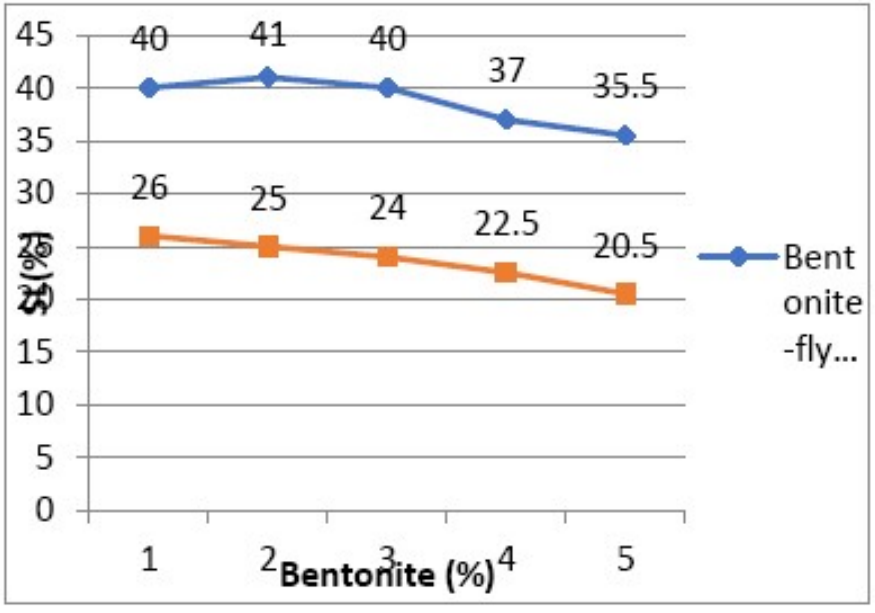

Fig.3 Variation of Shrinkage Limit with bentonite content

Determination of Differential Free Swell Modified Free Swell was determined according to IS 2730 (part XL)-1978. For the test 2 oven dried sample passing through $0.425 \mathrm{~mm}$ IS sieve weighing $20 \mathrm{gms}$ each were placed distinctly in two $100 \mathrm{ml}$ graduated cylinder. Concentrated water was used to fill 1 cylinder \& kerosene was used to fill another, up to the $100 \mathrm{ml}$ mark. In case of bentonite $10 \mathrm{gm}$ of sample were taken for the test. The DFS of bentonite is found to be $555 \%$. Bentonite shows very high swelling behavior because of its prominent cation exchange capacity. The final reading of volume of soil was taken after 24 hours to calculate free swell index.

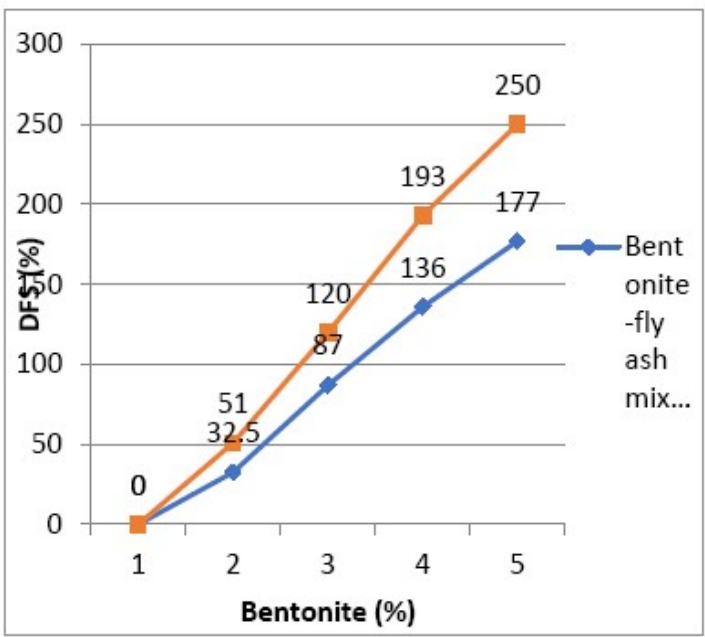

Fig. 4 Variation of DFS with bentonite content

\begin{tabular}{|c|c|c|c|c|}
\hline \multicolumn{2}{|c|}{ Bentonite } & $\begin{array}{c}\text { Bentonite fly } \\
\text { ash mixture }\end{array}$ & $\begin{array}{c}\text { Bentonite pond } \\
\text { ash mixture }\end{array}$ \\
\hline 0 & OMC & MDD & OMC & MDD \\
\hline 2 & 39 & 1.158 & 27 & 1.185 \\
\hline 4 & 38 & 1.194 & 26 & 1.222 \\
\hline 8 & 36 & 1.222 & 22 & 1.270 \\
\hline 12 & 34 & 1.248 & 21 & 1.32 \\
\hline 20 & 33.5 & 1.261 & 20.5 & 1.356 \\
\hline 0 & 32 & 1.0 & 20 & 1.37 \\
\hline
\end{tabular}

Table 3 Compaction characteristics of bentonite fly ash ash-bentonite mixtures.

Linear Shrinkage Index (Ls) In case of bentonite, formation of shrinkage cracks is the major issue to be tackled while considering it for waste containment liner. The bentonite used for the project work had a high linear shrinkage index of $44.65 \%$ and showed prominent desiccation cracks. When mixed with coal ash, there was a remarkable reduction in the shrinkage of the mixture. The linear shrinkage Index (LS) remained within $10 \%$ for both the coal ash-bentonite mixtures. The variation is presented in the figure 5.

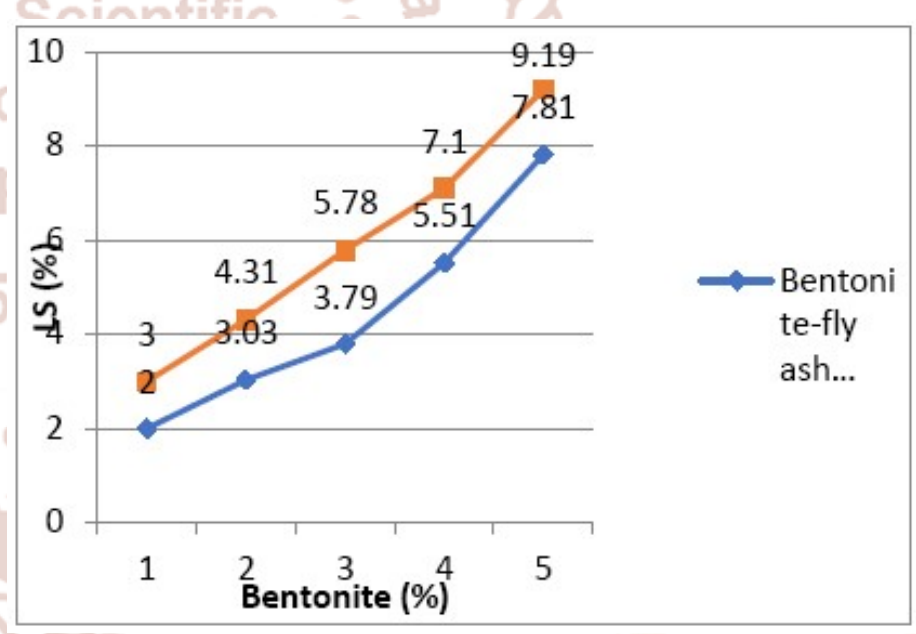

Fig. 5 Variation of LS with bentonite content

\section{Compaction Characteristics}

Light compaction test was carried out on specimens as per IS 2720 (Part VII) 1980. The compaction curves for fly ash-bentonite mixture and that of pond ashbentonite mixture was obtained and the $\mathrm{OMC}$ and MDD values are given in Table 3. These OMC and MDD values obtained from laboratory compaction test provide a reference point while estimating the actual water content of the field-compacted soil liner. The variation of MDD and OMC of the compacted coal ash bentonite mixtures are presented in the fig. 6 and fig 7. 
International Journal of Trend in Scientific Research and Development (IJTSRD) ISSN: 2456-6470

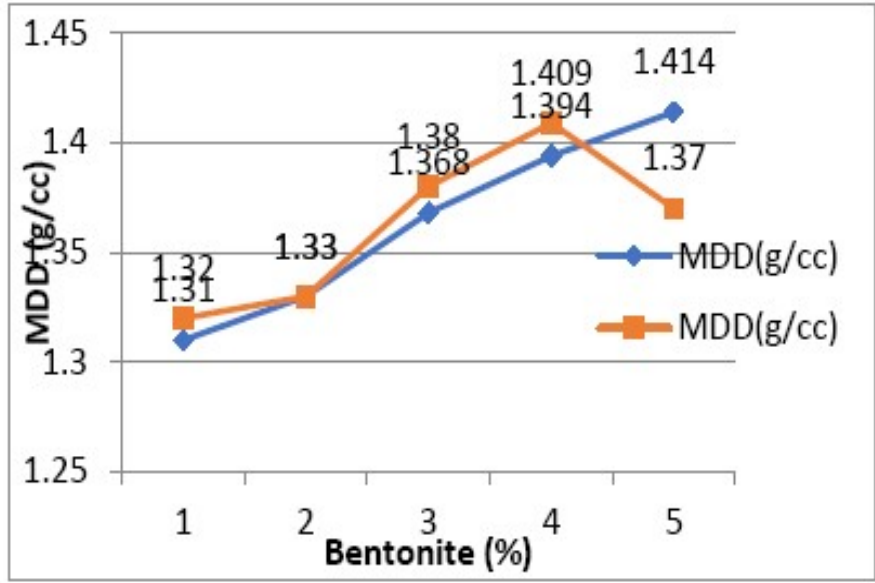

Fig. 6 Variation of MDD with bentonite content under Light Compaction

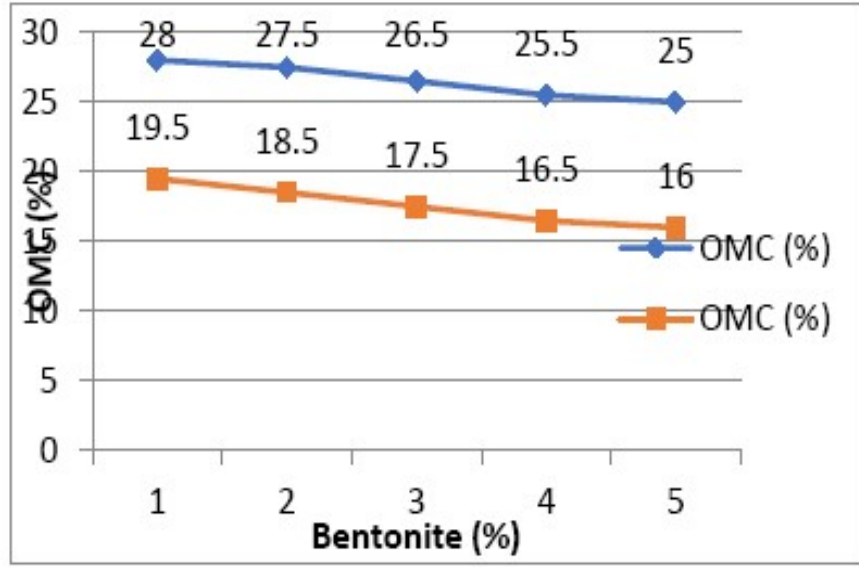

Fig. 7 Variation of OMC with bentonite content under Light Compaction

\section{Unconfined Compressive Strength}

The unconfined compressive strength tests were carried out on specimens prepared by compacting coal ash-bentonite mixtures at their MDD and OMC at a comp active energy of $593 \mathrm{~kJ} / \mathrm{m} 3$. The effects of adding bentonite on the UCS value of the mixtures are Presented in the figure 8

\begin{tabular}{|c|c|c|}
\hline \multicolumn{2}{|c|}{ Bentonite } & $\begin{array}{c}\text { UCS in KPa } \\
\text { content } \\
\text { Bentonite } \\
\text { pond ash } \\
\text { mixture }\end{array}$ \\
\hline 0 & Bentonite fly ash mixture & 47.579 \\
\hline 2 & 290.277 & 52.876 \\
\hline 4 & 323.619 & 79.952 \\
\hline 8 & 335.387 & 137.34 \\
\hline 12 & 347.155 & 215.82 \\
\hline 20 & 355.98 & 289.395 \\
\hline
\end{tabular}

Table 4 UCS of bentonite fly ash and bentonite pond ash mixture

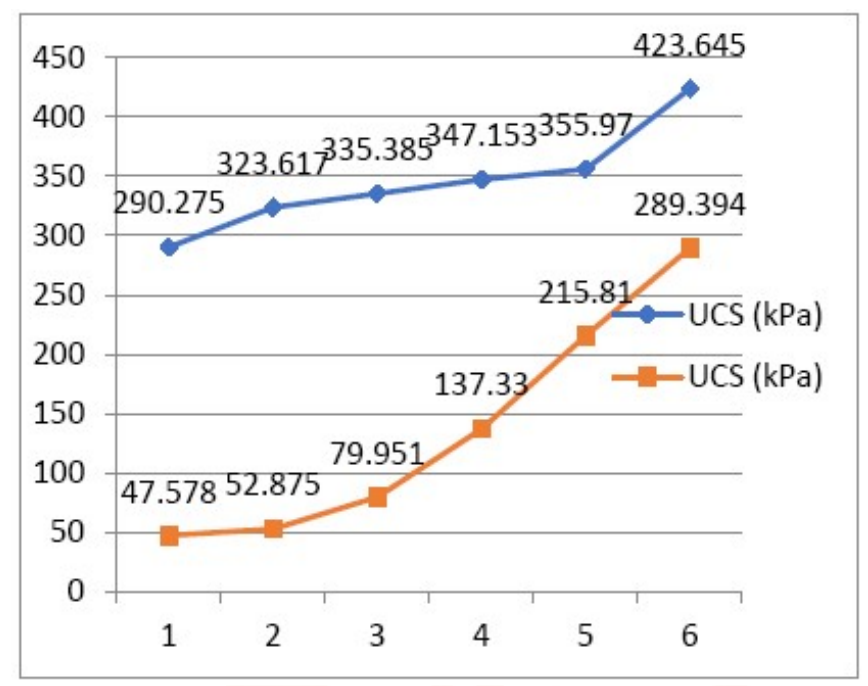

Fig.8 Variation of UCS with bentonite content.

\section{Permeability Characteristics}

The average value of coefficient of permeability of specimens are determined as per IS: 2720 (Part17) 1986 by Constant Head Permeability method. The values of coefficient of permeability of fly ash bentonite mixture and pond ash-bentonite mixture compacted at wet of optimum are given in Permeability characteristics of bentonite-pond ash mixtures

\begin{tabular}{|c|c|c|}
\hline \multicolumn{2}{|c|}{ Bentonite } & $\begin{array}{c}\text { Coefficient of } \\
\text { Permeability } \\
\text { (cm/sec) }\end{array}$ \\
\hline$(\%)$ & $\begin{array}{c}\text { Bentonite-fly ash } \\
\text { mixtures }\end{array}$ & $\begin{array}{c}\text { Bentonite-pond } \\
\text { ash mixtures }\end{array}$ \\
\hline 0 & $133 \times 10-7$ & $1384.5 \times 10-7$ \\
\hline 2 & $125 \times 10-7$ & $322.78 \times 10-7$ \\
\hline 4 & $123 \times 10-7$ & $12.414 \times 10-7$ \\
\hline 8 & $110 \times 10-7$ & $1.541 \times 10-7$ \\
\hline 12 & $9.99 \times 10-7$ & $0.502 \times 10-7$ \\
\hline 20 & $0.66 \times 10-7$ & $0.198 \times 10-7$ \\
\hline
\end{tabular}

Table 5 UCS of bentonite fly ash and bentonite pond ash mixture

It is reported that pond ash has higher permeability than fly ash because of it being coarser. With the addition of $0-4 \%$ bentonite, compacted pond ash bentonite mixture shows drastic reduction in the permeability, after which the value remains nearly constant. At about $12 \%$ bentonite content, it achieves a permeability of $0.5 \times 10-7 \mathrm{~cm} / \mathrm{sec}$. Fly ash being finer shows a low permeability which gradually decreases with the addition of bentonite. The mixture of compacted $80 \%$ fly ash and $20 \%$ bentonite report a permeability of $0.66 \times 10-7 \mathrm{~cm} / \mathrm{sec}$. 


\section{CONCLUSION}

Based on the experiments done on compacted coal ash amended with bentonite following results were drawn. The maximum dry density of both the coal ash increased and the OMC decreased with the increase in bentonite content. In case of pond ash-bentonite mixture similar value of MDD was achieved with a lower OMC of $25 \%$ than that of fly ash-bentonite mixture.

As the bentonite content increased in the compacted mixture, the permeability decreased. $20 \%$ bentonitefly ash mixture showed a permeability less than 1 $\times 10-7 \mathrm{~cm} / \mathrm{sec}$, which fulfilled the criteria for landfill liner.

Whereas for pond ash, it was achieved at $12 \%$ bentonite content in the mixture. An increase in bentonite content of $12 \%-20 \%$ induced plasticity in the coal ash-bentonite mixture which led to better bonding between particles upon compaction. The Differential Free Swell of the mixture increased with the addition of bentonite, resulting as a better sealant. There was a variation in Shrinkage Limit and Linear Shrinkage in the coal ash-bentonite mixture with the addition of bentonite, without formation of prominent shrinkage cracks.

In case of fly ash-bentonite mixture the variation of shrinkage limit fell in the range of $40 \%-35.5 \%$. For pond ash blended with bentonite the range was $26 \%$ $20.5 \%$. The UCS of compacted coal ash-bentonite mixture increased at a constant rate with the increase in bentonite content.

\section{SCOPE FOR FUTURE WORK}

1. Consolidation test can be accomplished on compressed bentonite -coal ash mixtures to know the compressibility of swelling pressure.

2. By using cracking tests proportions of cracks can be done.
Effect of lime and alkali on strength and durability of compacted clay liners could be investigated.

To see the result of reinforcing plastic fibers in linear material research work can be drawn out.

\section{REFERENCES}

1. Alam J. Alam M.M. and Ahmad A. (2012), "Seepage characteristics and geotechnical properties of fly ash mixed with bentonite", International Journal of Scientific and Engineering Approach, Vol. 4

2. Bello A.A. (2013), "Hydraulic conductivity of three compacted reddish-brown tropical soils", J. Civil Eng., Vol. 17, No. 5, pp. 939-948

3. Benson C.H., Jhai H. and Wang X. (1994), "Estimating hydraulic conductivity of compacted clay liners.” J. Geotech. Eng., Vol. 120, No. 2

4. Benson C.H. and Trast J.M. (1995), "Hydraulic conductivity of thirteen compacted clays.", Clays and Clay minerals, Vol. 43, No. 6, pp. 669-681

5. Coruh S. and Ergun O.N. (2010), "Use of fly ash, phosphogypsum and red mud as a liner material for the disposal of hazardous zinc leachate residue waste.”, J. Hazardous Materials, Vol. 173, pp. 468-473

6. Ghosh A. and Subbarao C. (1998), "Hydraulic conductivity and leachate characteristics of stabilized fly ash", J. Env. Eng., Vol. 124, No. 9 